\title{
The School Management in The Islamic-Based Excellent Vocational High School
}

\author{
Iswadi ${ }^{1 a^{*}} \&$ Herinto Sidik Iriansyah ${ }^{1, b}$ \\ 1 STKIP Kusumanegara, Jakarta Timur, DKI Jakarta 13770, Indonesia \\ a iswadi.kusumanegara@gmail.com; b herinto@stkipkusumanegara.ac.id \\ *Corresponding Author: iswadi.kusumanegara@gmail.com| Phone : +6287849460456
}

\begin{abstract}
Management plays an important role in building the quality of an institution. especially schools, consequently, quality management is needed to achieve these goals. The reality in the field shows that management is a discourse that has not yet received serious attention. Therefore, this study aims to gain a deep perception of the Management of Schools in Islamic Vocational High Schools. This study employs a qualitative approach with a case study method. The results of this study are classified into several steps. First, planning, Second, organizing, Third, mobilizing, Fourth, supervision. The results of the study indicate that in common the management of schools in Panglima Besar (PB) Soedirman Islamic Vocational School Jakarta takes place following the management functions applied in schools, this can be observed from the curriculum planning process carried out comprehensively and based on Islamic principles. Organizing activities in student affairs by linking all study programs and cross committees, the good student progress, and comprehensive supervision covering all supporting elements as well as supervision involving various stakeholders using the religious-based management approach. The harmonious coordination of the scholarly community-based academic scheme in the four fields of expertise makes Panglima Besar Soedirman Islamic Vocational School Jakarta one of the references to a superior Islamic-based vocational school in the Jakarta community.
\end{abstract}

Keywords: Vocational School; School Management; Islamic-based Management

\section{Introduction}

When an organization implement a properly managerial system, it will have a good organizational life, because every element of the organization moves in accordance with the rhythm of the management. However, it cannot be denied that every organization has limited human, money and physical resources to achieve the organizational goals. Success in achieving goals depends on the choice of objectives to be achieved by using resources effectively to achieve these goals.

One of the aspects that must be considered in order the organizational goals can be achieved as the desired is to pay attention to human aspects (Wenwen, Z. 2017) and human resource management (Cobanoglu, F., Sertel, G., \& Sarkaya, S. S. 2018). Recently, the development of human civilization raises the existence of technological developments directed towards the advanced technology and the increasing human needs and desires both in number, variety of types and levels of quality.

The development of education cannot be separated from the development of the world globally. The rapid advances in technology and information, realized or not, bring the contributing to the development of education (Wagener, M., \& Krogull, S. (2018). The government is very serious in handling the education sector because with a good education system it is hoped that the next generation will be qualified and able to adapt to live in the face of global competition. In realizing the quality of next-generation, of course, it must begin first by providing a good and systematic knowledge, namely through the education and teaching by the teachers in the school which includes vision and mission, curriculum, lecturer and staff competencies, infrastructure and facilities, teaching and learning process, supervision student development, and graduate competency. Choiriyah, (2011). The teacher certainly needs to do the planning, organizing, actuating, and controlling well on the preparation of education and teaching that will be given to the students, for this reason, the coordination of work must be functioned optimally in achieving educational programs in the 
schools. The work coordination needs to be considered so that school managers can give hope for the successful implementation of educational innovation programs.

There are several challenges in the school implementation, therefore, the education managers should be responsive and can learn the coordination of work in the application of education as knowledge and art to carry out their duties. Coordination is a step that is carried out systematically because it is the lifeblood of achieving school goals so it can improve the quality and achievement of the students. Therefore the education process must be able to create the global competitiveness, so the managers of education should make internal improvements towards the management in an organization both concerning the condition of human resources and the management system of its management.

Panglima Besar Soedirman Islamic Vocational High School Jakarta has the vision to create the characters, akhlakul karimah, creative, and have global insight and excellence. Without a clear vision and mission to be understood by all parties in the school, the effort to develop education will be futile work, therefore schools must be able to determine the vision and mission of education which will become the basis of reference in making programs and achieving Education Management Standards.

Nowadays, Panglima Besar Soedirman Islamic Vocational High School Jakarta has an Academic Culture which is characterized by Islamic values that not only produce the graduates who have global insight, but also graduates who have excelled in the field of science and entrepreneurship. In addition, this school is also able to accommodate the noble character as a foothold in managing education, so that the school can print future leaders who have high morality. Reviewing some of the excellence seen in Panglima Besar Soedirman Islamic Vocational High School Jakarta, the focus of this research is the management of Islamic-based schools in Panglima Besar Soedirman Islamic Vocational High School, Jakarta.

\section{Literature Review}

\subsection{Concept of Management}

Management is defined as a process in carrying out the important activity in the organization. In the Encyclopedia of Social Science, it is said that management is a process of implementing a particular goal held and supervised. Mulyasa (2013) defines management as one of the aspects that are regarding the management of the process to achieve the goals set for both short-term, mid-term and long-term goals. According to Daft (2011), management is the attainment of organization goals effectively and efficiently through planning, organizing, leading, and controlling organizational resources. (management is the achievement of organizational goals effectively and efficiently through the planning, organizing, implementing, and controlling of the organizational resources).This definition holds two important ideas: (1) the four functions of planning, organizing, leading, and controlling, (2) the attainment of organizational goals in an effective and efficient manner. (This definition has two important ideas: (1) four functions of planning and control, (2) the achievement of organizational goals effectively and efficiently.

Based on these definitions mentioned above, it can be concluded that management is an effort carried out jointly to determine and achieve the organizational goals with the implementation of planning, organizing, actuating, and controlling. Management is an activity in which the implementation is called management and the person is called a manager. According to Fayol in (Uzuegbu \& Nnadozie, 2015), there are five management functions carried out by managers, namely (1) planning, (2) organizing, (3) actuating, (4) coordinating, and (5) controlling.

\subsection{Function of Management}

In the management activities in an institution cannot be separated from the process of how the organizations or institutions use, manage it effectively and efficiently all available resources in the form of goods and humans. Thus, management will be able to function properly. The management function is found by several same scopes. The management which included: (1) planning management (2) organizing, (3) actuating, and (4) controlling. Furthermore, the four management functions that must be carried out by the principal as follows:

\section{a. Planning}

Planning is interpreted by several experts in various ways, according to Robbins (2012), planning is often called the primary management function because it establishes the basis for all the others things managers do as they organize, lead and control. It involves two important aspect, goals and plans. It means that planning is often said to be the main function of management because it is the basis of all things related to the manager in organizing, implementing and controlling. Two important things are the goal and plan. According to Andri Feriyanto, et al. Planning is a process of comparing, evaluating, and choosing the good alternatives and activities carried out in order to achieve the common goals. Planning is a rational process by using past facts and future expectations to illustrate future estimates. The outline planning is defined as the 
process of defining the organization's goal of making a strategy to achieve the goal, and developing a plan for an organization's work activities.

b. Organizing

Organizing is the division of work planned to be completed by workers' unit members, the determination of the relationship between effective work and them, and giving the reasonable environment and work facilities so that they work efficiently. According to Daft (2011), organizing in the process leads to the creation of organization structure, which defines how task is divided and resources deployed. Organization Structures in departement and formal task, formal reporting relationship. Organizing means the process of the division of tasks and responsibilities and authorities so that an organization can be created that can be mobilized as a unit in order to achieve the goals that have work mechanisms and procedures, job descriptions and placement of personnel in positions that are in accordance with their capabilities. Because the organization is a management tool to achieve the stated goals.

\section{c. Actuating}

According to Nadim, Chaudhry, Kalyar, \& Riaz (2012) motivation is processed by which a person effort are energized, directed and sustained toward attaining a goal. It means that motivation is a process where the people doing efforts to achieve the goals. Actuating is an action to make all group members try to achieve something with the managerial planning and organizational efforts. In general, the leaders want, mobilization or implementation to the subordinates in order to make them work as well as possible, and are expected not to deviate from the principles in advance. The types of actuating can be in the form of:

1. Orientation

Orientation is a way of direction by providing the necessary information so that activities are carried out properly.

2. Command

A command is requests and leadership to people who are under it to do or repeat a certain activity in certain circumstances. The program activities with their respective fields in the best and right way. Implementing or actuating are interpreted as the main activity in management that encourages and directs all subordinates to desire, aim, move to achieve predetermined goals and they have an interest and unite with the organization's business plan.

\section{Controlling}

Controlling is the fourth managerial functions after planning, organizing and actuating. As one of the functions of management, the oversight mechanism within an organization is absolutely necessary. According to Robbin (2012), controlling is a process of monitoring, comparing, and correcting work performance. It means that controlling is a process in which supervision compares and corrects/supervises in terms of work. According to Daft (2011), control has referred to the system process of regulating, organizational, activities to make them consistent with the expectation stabilised in a plant, target and standards of performance.

\subsection{School Management Concept}

The school management, in essence, has the same understanding as to the education management. However, management education has a wider range than the school management. In carrying out its activities, the school has a variety of works, it requires regularity in carrying out activities, the management has the works as follow ; (1) curriculum management, (2) student management, (3) personnel management (4) infrastructure management, (5) financial management, (6) management of school and community relations, (7) management of special services.

\section{Method}

This research uses a qualitative approach. This means that the data collected is not in the form of numbers, but the data comes from interview scripts, field notes, personal documents, and other official documents. The purpose of qualitative research is to describe the reality behind the phenomenon in-depth, in detail and in full. In accordance with the focus of research on School Management in Islamic-based superior vocational schools, the subjects in this study are: Principals, Deputy Principals, Teachers, Employees and Students.

The data collected by using (1) documents, (2) archived records, (3) interviews, (4) direct observations, (5) participant observations, (6) physical devices. This data collection technique is in accordance with the opinion of Yin (2017) that the evidence or data for the needs of case studies is based on six sources of evidence, namely (1) documents, (2) archive records, (3) interviews, (4) direct observations, (5) ) participant 
observation, (6) physical devices. States the several characteristics of a case study, namely: (1) identifying "cases" for a study; (2) The case is a system bound by time and place; (3) the case studies using various sources of information in data collection to provide a detailed and in-depth description of the response of an event; and (4) using a case study approach, the researchers will spend the time for describing the context or setting for a case. The reason why do the researchers choose this method because the Management of Schools in Islamic Vocational High School is based on a focus of problems that can be explored in depth. The focus of this research is based on the data that the researchers obtained through the various techniques both observation, interview and documentation study. The data obtained through the interview the principals and vice-principal and other stakeholders within the school management and also some productive teachers who directly involved in the teaching process. As a comparison, the writer gains some information from external information as a school committee, parents and alumnae. The data analyzed through interview, observation, documentation, and data reduction during the research process.

\section{Results and Discussion}

1. Planning

The planning coordination carried out by Panglima Besar Soedirman Islamic Vocational High School Jakarta shows that the preparation activities to be carried out are to understand and identify the various information relating to the work coordination. This includes several aspects including the student affairs, the curriculum, staffing, facilities and infrastructure, finance, public relations, and technical services. Every aspect of the preparation process is in accordance with the duties and functions of each field, so it can produce a decision on future implementation. This concept is in line with the Syaafudin's opinion that states the planning is essentially a series of activity processes in preparing the decisions about what is expected to happen. The decision can be in the form of events, circumstances, atmosphere, etc., and something that will be done, such as intensification, extensification, revision, renovation, substitution, creation and so on. The series of process activities are implemented so that these hopes can be realized into reality in the future. Furthermore, Sondang emphasized that planning is a preliminary stage that is absolutely necessary because many goals in the organization are not achieved due to poor planning. Therefore, the planning can be defined as "a whole process of thought and determination in a mature manner of things that will be done in the future in order to achieve predetermined goals".

It is in line with the data obtained through an interview with the principals as "The number of registrants are tripled than the number accepted. In planning new students, there are programs to be achieved namely; PB Soedirman Islamic Vocational School in Jakarta has programs, namely: (1) absorption of graduates in the world of work in accordance with the competency of the expertise program, (2) able to develop themselves in entrepreneurship so as to create new jobs, (3) able to compete in continuing into a more competitive environment, (4) and last but not least that is based on Islamic concepts, with the hope that all students always maintain harmony and order".

The management functions related to the planning can be used as a basis for analyzing the educational programs in the coordination of work at Panglima Besar Soedirman Islamic Vocational High School Jakarta to be well implemented and can be used as the key points before carrying out the activities at the school institution. The planning in Panglima Besar Soedirman Islamic Vocational High School Jakarta provides the opportunities for school personnel to hold the meetings regularly so that each stage is completed. Each plan is always communicated well between units or vice principals. The plan includes the resources needed, the tasks completed, the actions taken, and the schedule followed. (Thanomwan \& Buncha, 2014) says that the data analysis uses descriptive analysis namely frequency, percentage, average, standard deviation and inferential analysis such as correlation and Stepwise multiple regression. The results of the study indicate that the planning and organizational culture and the level of adequacy of school management are at a high level. In addition, the results show that there is a positive and significant relationship between organizational culture and the level of adequacy of school management at the level of significance

The related principles of the new education system are based on planning, learning achievement, establishing collective goals, collaboration, and shared values and vision, with the school work process based on strong teamwork, and on the teaching and learning processes associated with evaluation (Reid Ervin, Reid, \& Sandra Reid Ervin, 2011). In addition, (Tavares, 2015) said that careful planning which is part of school management is very influential in improving the quality of education and also producing graduates who are competent and ready to compete in the real world.

\section{Organizing}

The organizing means the process of tasks division and responsibilities, as well as an authority so that an organization can be created which can be mobilized as a unit in order to achieve the predetermined goals. 
So, the organizing includes the creation of work mechanism and procedure structures, the work descriptions and the placement of personnel in positions that are in accordance with their abilities because the organization is a management tool to achieve the stated goals. The organizing in achieving educational programs implemented in the school management at Panglima Besar Soedirman Islamic Vocational HighSchool Jakarta has also been applied in the division of tasks which include: student affairs, curriculum, staffing, facilities and infrastructure, financial services, public relations, and technical services. Organizing means the process of division of tasks and responsibilities and authority so that an organization can be created that can be moved as a unit in order to achieve the intended goals. So organizing includes the creation of work mechanism and procedure structures, job descriptions and placement of personnel in positions that suit their abilities. Because the organization is a management tool to achieve predetermined goals (Thanomwan \& Buncha, 2014).

The results of correlation analysis between variables indicate that all dimensions of the organizational culture of learning significantly related to the two dependent variables, namely organizational performance and organizational innovation. The data gathered from the interview revealed as the following quote. "The mobilization of each activity is carried out according to students' planning activities such as (1) additional tutoring given by the teacher especially subjects included in the national examination, (2) this, (3) teen red cross, (4) pasus, (5) sports (baskes, volley ball, taekwondo, pencak silat, futsal), (5) fashion shows \& recycling, and (6) language classes (smart class English and smart class french"). This further indicates that all dimensions of learning organizations are equally important for higher organizational performance (Hussein, Omar, Noordin, \& Ishak, 2016).

\section{a. The Student Affairs}

The Islamic Vocational High School Panglima Besar Sudirman Jakarta is an exemplary school in implementing education in schools. All elements of education are jointly involved in organizing the implementation of school programs. As well as the selection and determination of students based on their interests and talents. After the selection of new student admissions (PPDB), the class was then divided. The division of classes is adjusted to the students' achievement, namely on the basis of the results of the student's ability test after going through the selection process conducted by the school. The test results are adjusted to the four areas of expertise that already exist in the school profile, which include: (1) finance and institutions; (2) competency in sharia banking expertise; (3) office administration expertise competencies; and (4) animation skills competency. Next, determining the class division of students is based on their field of expertise. (Long, 2012) stated that the core objective of current student affairs is to comprehend how students are developed intellectually, psychosocial, and emotional and to create meaningful experiences that stimulate student development. Core values like care, assistance, equality and social justice inform many environments which are trying to be created by student professionals as the best condition for student learning and success. In helping students develop a stable identity, values, conflict resolution skills, communication skills, ethical standards, and tolerance, student professionals help students prepare for careers, leadership, and the role of civilians throughout their lives

\section{b. Curriculum}

The results of observation and interview conducted by the researchers at the curriculum committee representative field revealed that the curriculum used by Panglima Besar Soedirman Islamic Vocational High School Jakarta refers to the national curriculum. The national curriculum is adjusted to the field of student competence, while the excellence in the school is the application of a foreign language curriculum (Arabic, English, and Japanese). The curriculum is included in the subject of local content, this can be seen in the attachment of the curriculum and the student learning schedule. In addition, the indicators were also conveyed by the school principal in his interview that [it was true to follow up on existing curriculum discussions on additional local content included in the core of curriculum.

The findings of the researchers also revealed that Panglima Besar Soedirman Islamic Vocational High School Jakarta arrange a curriculum in accordance with the student character development. The teacher has an important role in moral education and character in the learning process. The teachers' role in moral and character education includes several aspects. First, exemplary. The teachers can provide good examples in the form of words and behaviour, especially in the school environment. Second, the teacher can act as an inspiration. A teacher can be uplifting the enthusiasm and potential possessed by the students to achieve outstanding achievement. Third, motivator. The teachers can motivate the students through appreciation for all students or through a fun learning process, and understand the different abilities possessed by the students. The findings are in line with the researches conducted by (Long, 2012)(Wu \& Jia-Jen-Hu, 2015), and (Bunaiasu, Stefan, Strunga, \& Popescu, 2013) that found the curriculum has a big impact on school successful. 


\section{c. Workforce}

The organizing to the teaching staff in the learning process has been carried out according to the main tasks and functions received by each teaching staff and conducted it easily. There were no violations committed by the teaching staff in carrying out the tasks given by the principal, this can be seen from the crowded activities of the students every day in receiving the material and implementing the direct practices according to the expertise. And this finding corresponds to the data obtained by (Qin \& Nembhard, 2015) that having an appropriate task could help the workforce management run accordingly.

\section{d. Facilities and Infrastructure}

The procurement of facilities for the infrastructure of Panglima Besar Soedirman Islamic Vocational High School Jakarta is adjusted to the number of the students, the social conditions, the culture, and types of services of Panglima Besar Soedirman Islamic Vocational High School Jakarta. All facilities available at Panglima Besar Soedirman Islamic Vocational High School Jakarta are in accordance with the standards of national education. The services that increases are directly proportional to the technology.

\section{e. Finance}

The financing is carried out to manage Panglima Besar Soedirman Islamic Vocational High School in Jakarta, the principal makes every effort to obtain the funds through the cooperation and production units which include the Central Government, Provinces, and foundations. Furthermore, this assistance has been enough and always delivered at Panglima Besar Soedirman Islamic Vocational High School Jakarta. In addition, the government funding sources and private funds, the finance are managed by the school, the receipt of reports, the report by the principal to the foundation. The financial management system in schools is based on the Islamic concept. The finance is managed honestly and fairly. All forms of transactions made refer to the administrative completeness so that there are no errors in issuing funds.

\section{f. Public Relations}

The role of public relations at Panglima Besar Soedirman Islamic Vocational High School in Jakarta has been running according to its function in increasing the promotion of school activities in the outside world, both through media and verbally information to other parties involved. The implementation of public relations management at Panglima Besar Soedirman Islamic Vocational High School Jakarta works well so that schools become more popular, as well as the student achievements can be published. In addition, the public relations collaborates with the production units to conduct the comparative studies and exchange of internships. The public relations department also bridges various partnership activities and internships at home and abroad.

\section{g. Technical Services}

The technical services have also been done well. The existence of cooperation in the form of MoU with the community health centre to provide services to the students' health. The management of technical services at Panglima Besar Soedirman Islamic Vocational High School Jakarta, on the indicator of the principal's technical services, stated that he had carried out the management of the technical services which included library services, health services, security services, and entrepreneurial services.

\section{Actuating}

The implementation emphasizes to the activities that are directly related to the people in the organization. The implementation are planning and organizing, where all components that are in one system and one organization work together in accordance with their respective fields to be able to realize the goals.

The interview showed that "Implementation is adjusted according to the local content added by foreign languages (Arabic, English and Japanese), in addition to local content taught in all fields of study expertise".

\section{a. The student affairs}

Students are a means to carry out the educational programs, they always have a high enthusiasm for all the activities carried out by the teacher, any form of the implementation of activities related to the teachers' education do not get obstacles in dealing with the students. The management of student coaching is something that supports the achievement of learning outcomes because student coaching is related to the development of skills, character, and personality. The enhancement in extracurricular training in the afternoon carried out by various activities such as additional tutoring provided by the teacher, especially on subjects included in national exams, spiritist, red cross youth, special forces, sports (basketball, volleyball, taekwondo, pencak silat, futsal), dance and music arts, and language classes (English smart class).

\section{b. Curriculum}

The curriculum implementation has been adjusted to the field of expertise of each teacher. The results of 
the study revealed that the planning of learning programs at Panglima Besar Soedirman Islamic Vocational High School Jakarta had been carried out on the students according to the schedule and program that had been made. The program meeting activities are delivered clearly and structurally and each teacher can provide input, suggestions, and considerations on the concepts offered. Furthermore, the decision-making is chosen to be carried out in accordance with the applicable curriculum.

\section{c. Workforce}

Generally, it can be said that the human resources within the Panglima Besar Soedirman Islamic Vocational High School in Jakarta, have understood the importance of work coordination organizers. This is not as a momentary interest but is a long-term interest in order to achieve the educational goals that can improve people's welfare. The findings of this study also revealed that during the actuating phase at PANGLIMA BESAR Soedirman Islamic Vocational High School Jakarta, the aspect of the workforce, in particular, had its own concept in equipping the educators. This can be seen from the application of the Islamic concept which is guided by the Qur'an Surah At-Taubah that humans in their work are adapted to their respective skills. Skills can be seen from the mastery of knowledge and experience possessed to place them in certain positions within an institution. In addition, they are given the duties and responsibilities in implementing a good moral and character formation for students. This can be seen from the increase in human resources at the school which has provided the opportunities for the teachers to take part in various training activities, both at home and abroad, which have been proven from the training certificate owned by the teacher.

\section{d. Facilities and Infrastructure}

The management of infrastructure in Panglima Besar Soedirman Jakarta Islamic Vocational High School is all funds have been used properly. Some facilities are ordered to the outside of the area, some can be made in the area around Panglima Besar Soedirman Islamic Vocational High School Jakarta, which is certainly in accordance with the instructions from the head of Panglima Besar Soedirman Islamic Vocational School Jakarta, both in terms of quality and quantity. In addition to the security conditions, the infrastructure has also been considered in depth.

\section{e. Finance}

Financial management in terms of financing to manage Panglima Besar Soedirman Islamic Vocational High School Jakarta. The principal has made every effort to get the funds through the cooperation and production units, so that there is independence in the finance Panglima Besar Soedirman Islamic Vocational High School Jakarta, on financial indicators, has tried to do of Panglima Besar Soedirman Islamic Vocational High School Jakarta, both from the Central Government, the Province, and the foundation. So far, this assistance has been sufficient and always delivered at the Panglima Besar Soedirman Islamic Vocational High School in Jakarta.

\section{f. Public Relation}

The implementation of the public relations management at Panglima Besar Sudirman Islamic Vocational High School Jakarta works with the representatives of the public relations sector to create a good partnership. The presence of public relations in this school is better and most popular and well-publicized in the process and achievements of the students at Panglima Besar Soedirman Islamic Vocational High School Jakarta, through the collaboration and production units so there are many institutions conduct the comparative studies and exchange of internships. In addition, the public relations field is also tasked to improve the students' character in learning. The public relations sector can promote the character education by making commitments with the school residents, parents of students, and community leaders in order to support the implementation of moral education and character of students at Panglima Besar Soedirman Islamic Vocational High School Jakarta

\section{g. Technical Services}

The management of technical services at Panglima Besar Soedirman Islamic Vocational High School Jakarta which includes the library services, health, security, and entrepreneurship. The technical services work together with the representatives of technical services, so the good cooperation and partnerships are formed to produce a form of collaboration in terms of libraries. Students can obtain book lending services online or directly, while the health services include the activities in UKS (School Health Unit) in the form of giving and examining the students' physical health. In addition, the field of entrepreneurship provides opportunities for the students to increase their creativity and financial, so they can increase the income. With this technical service, the school is better and able to develop the students' soft skills in various skills.

\section{Controlling}

The controlling carried out in the school management is adjusted to the provisions in planning. The management, measurement, and improvement to the implementation of subordinate work are planned so 
that the objectives can be carried out optimally. All functions that have been compiled will not run effectively without a supervisory function. Basically, this controlling includes four elements, namely: (1) standard-setting; (2) determination of implementation measures; (3) measuring the actual implementation and comparing with the standards set; and (4) taking the corrective actions needed if the implementation deviates and does not comply with the standards set. P4:The interview with the principal showed that "Supervision and controlling are carried out by the school principal, vice-minister of curriculum, and the city education office. Supervision is always carried out, namely the learning process that includes local content both nationally determined and superior local content included in the local content".

a. The student affairs

Panglima Besar Soedirman Islamic Vocational High School Jakarta is a school that is very popular with the students. This situation can be seen from the number of new student admissions every year. As a basis for comparing the student admissions, each year it is seen that the number of students who register is increasing. However, the school prepares and plans for the acceptance of the new students. Planning for acceptance of new students aims at the program to be achieved, which includes: (1) absorbed the graduates in the world of work in accordance with the competency of their expertise program; (2) able to develop themselves in entrepreneurship, so that they can create new jobs; and (3) able to compete in continuing a higher level.

\section{b. Curriculum}

Besides using the national curriculum, Panglima Besar Soedirman Islamic Vocational High School Jakarta also adds productive program expertise. Operationally the school learning program plan includes two main activities which include calmness and the division of tasks. The division of teacher assignments in terms of supervision of learning programs is carried out according to the field of study being taught. In addition, the formation of ceremonies on Mondays and other days is divided based on the mutually agreed upon. The preparation of a lesson plan (RPP) is not done by a teacher but is arranged together by several teachers who teach at the same school level. Besides the preparation of the lesson plan carried out together between the subject teachers, the principal also gave the trust to the teacher to oversee the activities of moral education through the class program. The homeroom teacher is given full responsibility for the problems faced by the students in the class. Starting from the problems in learning activities that cause the student achievement to decline until the problem of morality and character of the students. With these various problems, the homeroom teacher can explore the root of the problem and do the coaching specifically.

\section{c. Workforce}

Through controlling, it can reveal the extent of success with the curriculum planning in providing achievements to the students. The controlling carried out by the educators is in the form of evaluation to assess the success of the planned program. The procedure for evaluating the improvement of morals and manners is formulated according to the quality assurance and school standards that must be mastered by the students. The teacher is given the task and responsibility to provide the reports on the results of moral attainment and character of the students according to the subjects taught. From the results of the observations, it can be described to get the results of achieving the quality standards of the students who are informed in a coordinated manner to the homeroom teacher. The evaluations continue to be made at any time, both in the class hours and outside class hours, and every place, both in class and outside the classroom, by observation and recording. By carrying out these activities, of course, it will be easier for the teachers to conduct the character building for the students who are considered to be still not good, in terms of morals and manners.

\section{d. Public Relations}

The implementation of public relations management at Panglima Besar Soedirman Islamic Vocational High School Jakarta, on the indicator of community relations among principals, has tried to collaborate with the representatives of the public relations sector in order to create good cooperation and partnerships. The existence of the public relations in this school has become better and most popular, as well as publicized both the process and the achievements of the students in Vocational Schools. Through the collaboration and production units, of course, many schools conduct the comparative studies and exchange of internships. The public relations department also bridges a variety of partnership activities and further domestic and foreign internship representatives in the public relations sector.

e. Technical Services

Panglima Besar Soedirman Islamic Vocational High School Jakarta developed the students' soft skills in various skills. The controlling is carried out by the foundation and also the school committee. So the various activities that exist in Panglima Besar Soedirman Islamic Vocational High School Jakarta cannot be 
separated from the monitoring. In addition, reporting is one of controlling form carried out by the government through reporting to the education office. Controlling is one of the organic functions of the management, which is a process of leadership activities to ensure and guarantee that the goals and objectives, as well as organizational tasks, have been carried out properly in accordance with the plans, policies, instructions, and provisions that have been set and that apply.

\section{Conclusion}

Based on the results of data analysis, it was concluded that the results of this study included several aspects, which included planning, organizing, actuating, and controlling. The coordination in the field of planning is to carry out the preparation process in accordance with the duties and functions of each field so they are able to bring forth to a decision on implementation in the future. The management functions related to the planning serve as the basis for analyzing educational programs in coordinating work at Panglima Besar Soedirman Islamic Vocational High School Jakarta.

The organizing activities in the student affairs involving all study programs and cross committees at the acceptance of the new student. The curriculum is synchronized with the needs of existing study programs, according to the expertise. The workforce aspect with the placement of teacher's abilities, experience, and position. The financial aspects are coordinated between the school principals, representatives, and treasurers in the needs of the budget. The field of facilities through the inventory of goods is carried out by recapitulation of goods data. The public relations party collaborates between institutions, technical services work together to carry out service footprints on students. The actuating activities in the student field are reconciling the needs of the students and the capacity of students. The curriculum is placed and shared with the study program, then a new syllabus is made in the new school year. The field of the workforce gives freedom to the teachers in moving their ideas according to their competencies and performance standards. The finance is issued based on the needs and requests. The facility moves the unit by sharing the needs of each space and field. The public Relations moves the units and systems of collaboration through the MoU that was made. The technical services are more about providing direct services to the students and teachers.

The controlling coordination activities in the field of student affairs through the acceptance of the new student committee report, the progress of student learning, and improving teacher performance. The curriculum is overseen by the curriculum. The infrastructure facilities are routinely checked, the damaged goods are replaced and repaired. The field of work is supervised by the principal and makes the regular $\mathrm{L} \backslash 45 \mathrm{reports}$ to the education office. The public relations sector through a network of internships and work units (BKK) conducts the evaluations every year. The finance reports the results of production units every month. more technical services on reporting the performance of units such as school health unit, libraries, pencak silat, and so on. The coordination activity in the implementation of the Competency Test Place in Panglima Besar Sudirman Islamic Vocational High School Jakarta involved all study programs and cross committees. All parties involved have already known their respective main tasks and functions. The information about the main tasks and functions is determined in a coordination meeting. Each field has known its main tasks and functions so that the implementation of a competency test place can run smoothly.

\section{Recommendation}

1. For the government, there needs to be a more progressive comprehensively related to international standard development.

2. The use of electronic media, especially television media, needs to be taken seriously so that school information can be absorbed and understood well by the public. Especially in the academic community in the Jakarta city and in general.

3. The direct information, especially for the parents, needs to be intensive, considering the parents, administration, teachers and staff about the importance of quality of management services and Panglima Besar Soedirman Islamic Vocational High School Jakarta

4. The support from the government elements starting from the neighbourhood, subdistrict head, the regent, and the governor needs to continue to be realized, especially in facilitating the needs of space, both for activities inside and outside, so that the implementation of the school can be in the form of international standard school.

5. These elements of government support are also needed, especially in stimulating the active participation of community members, both the general public and the industrial community to facilitate theneeds. 


\section{References}

Bunaiasu, C., Stefan, M., Strunga, A., \& Popescu, M. (2013). Impact Study Regarding Constructivist Curriculum's Management of Teacher Training. Procedia - Social and Behavioral Sciences, 78, 145-149. https://doi.org/10.1016/j.sbspro.2013.04.268

Cobanoglu, F., Sertel, G., \& Sarkaya, S. S. (2018). Human Resource Management Practices in Turkish Education System (Denizli Case). European Journal of Educational Research, 7(4), 833-847.

Daft, R. L. (2010). New Era of Management. Ninth Edition. Canada: South-Western.

Feagin, J. R., Orum, A. M., \& Sjoberg, G. (Eds.). (1991). A case for the case study. UNC Press Books

Hussein, N., Omar, S., Noordin, F., \& Ishak, N. A. (2016). Learning Organization Culture, Organizational Performance and Organizational Innovativeness in a Public Institution of Higher Education in Malaysia: A Preliminary Study. Procedia Economics and Finance, 37(16), 512-519. https://doi.org/10.1016/s2212-5671(16)30159-9

Long, D. (2012). The foundations of student affairs: A guide to the profession. Environments for Student Growth and Development: Librarians and Student Affairs in Collaboration, 1-39. Retrieved from http://ir.library.illinoisstate.edu/fpml\%0Ahttp://ir.library.illinoisstate.edu/cgi/viewcontent.cgi?articl $\mathrm{e}=1028 \&$ context $=\mathrm{fpml}$

Mulyasa. (2013). ManajemenBerbasisSekolahProfesional. Bandung: PT RemajaRosdakarya.

Qin, R., \& Nembhard, D. A. (2015). Workforce agility in operations management. Surveys in Operations Research and Management Science, 20(2), 55-69. https:// doi.org/10.1016/j.sorms.2015.11.001

Reid Ervin, S., Reid, S., \& Sandra Reid Ervin, by. (2011). The Aquila Digital Community The Relationship Between Teacher Collaboration and Student Achievement Recommended Citation The University of Southern Mississippi The Relationship Between Teacher Collaboration And Student Achievement.

Robbins, S. P. (2012). Management. San Diego: Prentice-Hall.

Tavares, P. A. (2015). The impact of school management practices on educational performance: Evidence from public schools in São Paulo. Economics of Education Review, 48, 1-15. https://doi.org/10.1016/j.econedurev.2015.05.002

Thanomwan, P., \& Buncha, P. (2014). Relationship between Organization Culture and Sufficiency School Management. Procedia - Social and Behavioral Sciences, 116, 796-801. https://doi.org/10.1016/j.sbspro.2014.01.300

Uzuegbu, C. P., \& Nnadozie, C. O. (2015). Henry Fayol's 14 Principles of Management: Implications for Libraries and Information Centres. Journal of Information Science Theory and Practice, 3(2), 58-72. https:// doi.org/10.1633/jistap.2015.3.2.5

Wu, Y.-L., \& Jia-Jen-Hu. (2015). Skill Learning Attitudes, Satisfaction of Curriculum, and Vocational Selfconcept among Junior High School Students of Technical Education Programs. Procedia - Social and Behavioral Sciences, 174, 2862-2866. https://doi.org/10.1016/j.sbspro.2015.01.980

Yin, R. K. (2017). Case Study Research and Applications. Retrieved from http://ir.obihiro.ac.jp/dspace/handle/10322/3933

Wagener, M., \& Krogull, S. (2018). Educating world citizens-empirical implications and the contribution of Geography education. Review of International Geographical Education Online (RIGEO), 8(2), 186.

Wenwen, Z. (2017). School-Family Cooperation, Social Closure, Educational Equality and Excellence: Evidence from China. Research in Educational Administration 